\title{
Morbidity Pattern in Psychiatric Ward in a Tertiary Care Hospital in Eastern Nepal
}

\author{
Basnet M1, Sapkota N², Limbu S33, Baral DD4, Rai N5
}

1. Associate Professor, Department of Psychiatry, BPKIHS, Dharan, Nepal 2. Additional Professor, Department of Psychiatry, BPKIHS, Dharan, Nepal 3. Senior Resident, Department of Psychiatry, BPKIHS, Dharan, Nepal 4. Assistant Professor, School of Public Health and Community Medicine, BPKIHS, Dharan, Nepal 5. Lecturer, Department of Psychiatry, KIST Medical College, Lalitpur, Nepal

$\underline{\text { E-mail *Corresponding author : madhurbasnet@ gmail.com }}$

\section{Abstract}

Introduction: Worldwide, the morbidity of psychiatric illnesses is on the rise. Quality in-patient services are a part of quality mental health services provision. Knowledge about the pattern of illness among patients admitted to the ward could help the service providers to plan better and provide better services. This study was undertaken to explore the clinico-demographic profile of patients admitted to psychiatric ward at BPKIHS..

Material And Method: This is a hospital based retrospective and cross-sectional study. After ethical approval from the Institutional Review Committee, the data of all patients admitted to Psychiatry Ward from 1st January 2007 to 31st December 2016 were collected from the data-base of Medical Records Section. The diagnoses were made according to the ICD-10 criteria. 3687 admissions were processed for the analysis.

Results: Of the 3687 admissions, 2183(59.2\%) were male and 1504 (40.8\%) were female. The age range was 4-92 years with mean age of $32.4( \pm 12.6)$ years. The majority of the admissions $(62.5 \%)$ were from Sunsari $(1159,31.4 \%)$ and surrounding districts $(1147,31.1 \%)$. Mood disorders were the commonest diagnoses $1788(48.5 \%)$ followed by schizophrenia, schizotypal and delusional disorders $829(22.5 \%)$ and psychoactive substance use disorders 813(22.1). 92\% of patients admitted were improved on discharge and three cases expired in the ward. Out of 3687 admissions, 957(26\%) were readmissions.

Conclusion: Mood disorders were the commonest diagnosis among the admitted patients. Outcome of hospital stay was good with 92\% discharged in improved condition and only three mortalities in 10 years duration. Address seems to significantly affect the service utilization.

Keywords: Psychiatric illness, Inpatient, Nepal

\section{INTRODUCTION}

Worldwide, the morbidity of psychiatric illnesses is on the rise. ${ }^{1}$ However, the gap of the need for mental health services and the provision of available services is vast and even many of those who do get the services do not get quality services. ${ }^{1}$ Modern mental health services in Nepal started almost fifty years back but still the services are grossly inadequate. In-patient psychiatric services in Nepal are being provided mainly in the psychiatric units of medical colleges and university hospitals and some private hospitals but this is grossly inadequate. The WHO-AIMS report reported 17 community- 
based psychiatric inpatient units were available in the country for a total of 1.00 beds per 100,000 population and treated 3.91 patients per 100,000 population. ${ }^{2}$ A recent study reported a total of 1.5 beds per 100,000 population and just 60 psychiatrists for a population of almost 30 milllions. ${ }^{3}$ The psychiatric department of B.P. Koirala Institute of Health Sciences(BPKIHS), Dharan(with 30 beds capacity) and Koshi Zonal Hospital, Biratnagar (with 4 beds capacity) had been the only facilities providing in-patient services to the entire population of 5.83 millions $^{4}$ in the Eastern Development Region till eight years back. Some additional beds are now available in other private medical colleges and private hospitals.

Quality in-patient services are a part of quality mental health services provision. Longer inpatient stays could lead to higher direct and indirect costs and it could also isolate the patient from their social networks leading to maladaptive processes in the patients. 5 Moreover in context of Nepal where the health care spending is mainly based on out-of-pocket money, it could lead to catastrophic costs further compounding the situation. The average psychiatric in-patient Length of Stay(LoS) in Nepal was found to be 18.85 days. $^{2}$ In Nepal, the average cost of antipsychotic or antidepressant medicines was found to be around $8 \%$ of the daily wage of a labourer. ${ }^{2}$ Various factors including socio-demographic, clinical and system-based parameters have been found to affect the length of stay among patients admitted to psychiatric wards. ${ }^{6-11}$ Mental disorders have been associated with longer duration of stay than physical disorders. 12 Similarly, psychosis, female gender and larger hospital size were associated with longer hospital stay while discharge against medical advice, young or middle ages, being detained and being married were some of the factors associated with shorter hospital stay. ${ }^{11}$ Goldstein et al. have suggested that in addition to diagnosis, other factors such as age and treatment setting contribute to long stays and high costs. ${ }^{13}$ In another study done in South London, the mean age of the patients was 39.1 yrs (SD \pm 12.4$)$ with $56 \%$ of patients being male. Psychotic disorders (Schizophrenia and other psychotic disorders-42\%) were the commonest diagnosis followed by mood disorders $(28 \%)$, drugs and alcohol disorders (11\%), neurotic and anxiety disorders (9\%) and personality disorders $(6 \%) .{ }^{14}$

Knowledge about the clinico-demographic profile of the patients admitted to psychiatric wards could help the service providers as well as the administrators to plan better and provide better services.

\section{MATERIAL AND METHOD}

This was a retrospective cross-sectional study conducted at B. P. Koirala Institute of Health Sciences(BPKIHS), Dharan with the objective of knowing the morbidity pattern of patients admitted to the psychiatric ward at BPKIHS along with sociodemographic profile. BPKIHS is the tertiary referral centre in the Eastern Development Region of Nepal. The psychiatric department of the institute provides out-patient, in-patient, 24-hour emergency services and consultation liaison services. The department has 30 bed capacity in-patient ward. The psychiatric diagnoses of all patients admitted in the ward are made according to the ICD-10 CDDG criteria by consultant psychiatrists after adequate detail work up. The medical record section of the institute keeps a well maintained electronic database with records of all inpatients according to the ICD-10 diagnostic categories. The study protocol was submitted to the Institutional Review Committee and ethical approval was taken. The data of all patients admitted to the psychiatry ward from 1st January 2007 to 31st December 2016 were extracted from the database of the medical record section using all precautions to conceal any identity of the patients. The data were entered into MS Excel, cleaned and processed for analysis using the SPSS version 11.5. There were a total of 3699 admissions during the study period out of which two were mistake admissions and ten admissions were cancelled the same day. These twelve admissions were excluded from the study and remaining 3687 admissions were analyzed. For descriptive statistics, percentage, mean, range and standard deviation were calculated and presented in tabular and graphical presentation.

\section{RESULT}

There were a total of 3687 admissions. There were $1504(40.8 \%)$ female admissions and 
2183(59.2\%) male admissions of which $2730(74 \%)$ were single admission and 957(26\%) readmissions.

Table 1: Socio-demographic Characteristics of the Subjects

\begin{tabular}{|c|c|c|c|}
\hline $\begin{array}{l}\text { Characteristic } \\
\mathrm{s}\end{array}$ & Categories & $\begin{array}{l}\text { No of } \\
\text { Patient } \\
\text { S }\end{array}$ & $\begin{array}{l}\text { Percentag } \\
\text { e }\end{array}$ \\
\hline \multirow{3}{*}{ Age Group } & $\begin{array}{l}\text { Children } \\
\text { and } \\
\text { Adolescents }\end{array}$ & 497 & 13.5 \\
\hline & Adults & 3058 & 82.9 \\
\hline & $\begin{array}{l}\text { 60years and } \\
\text { above }\end{array}$ & 132 & 3.6 \\
\hline \multirow{2}{*}{ Gender } & Female & 1504 & 40.8 \\
\hline & Male & 2183 & 59.2 \\
\hline \multirow{4}{*}{ Address } & Sunsari & 1159 & 31.4 \\
\hline & $\begin{array}{l}\text { Surrounding } \\
\text { Districts of } \\
\text { Sunsari }\end{array}$ & 1147 & 31.1 \\
\hline & $\begin{array}{l}\text { Other Eastern } \\
\text { Terai } \\
\text { Districts and } \\
\text { others }\end{array}$ & 964 & 26.1 \\
\hline & $\begin{array}{l}\text { Other Eastern } \\
\text { Hill Districts }\end{array}$ & 417 & 11.3 \\
\hline \multirow{6}{*}{ Religion } & Hindu & 3258 & 88.4 \\
\hline & Buddhist & 56 & 1.5 \\
\hline & Christian & 53 & 1.4 \\
\hline & Kirat & 198 & 5.4 \\
\hline & Islam & 42 & 1.1 \\
\hline & Others & 80 & 2.2 \\
\hline \multirow{7}{*}{ Occupation } & $\begin{array}{l}\text { Unemploye } \\
\mathrm{d}\end{array}$ & 347 & 9.4 \\
\hline & $\begin{array}{l}\text { Self } \\
\text { employed }\end{array}$ & 938 & 25.4 \\
\hline & $\begin{array}{l}\text { Service } \\
\text { holder }\end{array}$ & 147 & 4.0 \\
\hline & House wife & 1057 & 28.7 \\
\hline & Farmer & 580 & 15.7 \\
\hline & Students & 604 & 16.4 \\
\hline & $\begin{array}{l}\text { Not } \\
\text { mentioned }\end{array}$ & 14 & 0.4 \\
\hline
\end{tabular}

The mean age of the patients was 32.4 years $( \pm 12.6)$ with age range from $4-92$ years and old age constituted $3.6 \%$ of the admissions. Majority of patients $(62.5 \%)$ were from Sunsari and surrounding districts, with almost onethird(31.4\%) from Sunsari district alone.
Majority (88.4\%) of patients were Hindu by religion. Housewives constituted $28.7 \%$ of the admissions and only $9.4 \%$ were recorded to be unemployed. Mood disorders were the commonest diagnosis(48.5\%) followed by schizophrenia, schizotypal and delusional disorders $(22.5 \%)$ and psychoactive substance use disorders(22.1\%). Psychiatric diagnosis was missing in 61 patients $(1.7 \%)$ that could be because of error in entering the diagnoses into the database as all those missing cases had one or other medical co-morbidity. Psychiatric comorbidities were recorded in $6 \%$ of the cases and medical co-morbidity was noted in $320(8.7 \%)$ of the admissions. 66(1.8\%) admissions had diagnosis of suicidal attempts. The frequency of admissions was maximum(10.2\%) in the month of March and minimum(6.6\%) in September while LoS was maximum(21.8days) in May and minimum(17.7\%) in March. The mean LoS during the study period was 19.4 days $( \pm 13.1)$ with range of 1-124 days. The bed occupancy rate was $65.2 \%$. The overall outcome during the study period was good with $92 \%$ patients discharged in improved state and only three $(0.1 \%)$ deaths in ten years period. Similarly, all patients who had expired had medical comorbidity. Those with mixed diagnosis were younger(mean age-30.29 years) as compared to those with single diagnosis and the association was significant $(p=0.009)$. Similarly, females were younger(mean age 31.8 years) as compared to males(mean age 32.9 years) in our study sample and the association was significant $(\mathrm{p}=0.008)$.

\section{DISCUSSION:}

According to the Nepal Census 2011,15 the male to female ratio in the Eastern Development Region was 92.37:100 but in our study, more males(59.2\%) were admitted as compared to females. The WHO-AIMS study in Nepal had found that $54 \%$ of inpatients were male. ${ }^{2}$ Similar findings have been noted by other studies, $7,16,17$ 
Table 1: Clinical Characteristics of the Subjetcs

\begin{tabular}{|c|c|c|c|}
\hline Characteristics & Categories & No. of Patients & Percentage \\
\hline \multirow{4}{*}{ Length of Stay } & 7 days & 468 & 12.7 \\
\hline & 8-14days & 1102 & 29.9 \\
\hline & 15-28days & 1446 & 39.2 \\
\hline & $>28$ days & 671 & 18.2 \\
\hline \multirow{8}{*}{$\begin{array}{l}\text { Disease } \\
\text { Category }\end{array}$} & Organic, including symptomatic, mental disorders & 39 & 1.1 \\
\hline & $\begin{array}{l}\text { Mental and behavioural disorders due to psychoactive } \\
\text { substance use }\end{array}$ & 813 & 22.1 \\
\hline & Schizophrenia, schizotypal and delusional disorders & 829 & 22.5 \\
\hline & Mood Disorders & 1788 & 48.5 \\
\hline & Neurotic, stress-related and somatoform disorders & 99 & 2.7 \\
\hline & Others & 25 & 0.7 \\
\hline & Suicide attempt & 33 & 0.9 \\
\hline & Not mentioned & 61 & 1.7 \\
\hline \multirow{5}{*}{ Outcome } & Absconded & 119 & 3.2 \\
\hline & Expired & 3 & 0.1 \\
\hline & Improved & 3392 & 92.0 \\
\hline & LAMA & 139 & 3.8 \\
\hline & Others & 34 & 0.9 \\
\hline \multirow{3}{*}{ Admission from } & Psychiatry OPD & 3568 & 96.8 \\
\hline & Medicine Ward & 98 & 2.7 \\
\hline & Others (Gynae and Obstetrics, ENT, Surgery, Ortho) & 21 & 0.6 \\
\hline \multirow{2}{*}{$\begin{array}{l}\text { Medical Co- } \\
\text { morbidity }\end{array}$} & No & 3367 & 91.3 \\
\hline & Yes & 320 & 8.7 \\
\hline \multirow{2}{*}{ Readmission } & No & 2730 & 74.0 \\
\hline & Yes & 957 & 26.0 \\
\hline
\end{tabular}

One of the reasons for this male-female differences in our study could be gender discrimination towards females as it's one of the major social problems in Nepal. ${ }^{18,19}$ According to the national census 2011, the age group distribution was $40 \%$ children and adolescents, $51 \%$ adults and $9 \% 60$ years and above. ${ }^{15}$ The distribution in our study sample consisted of $13.5 \%$ children and adolescents, $82.9 \%$ adults and $3.6 \%$ 60years and above, indicating proportionately more patients in the age group 20-59 years were being admitted. In a study done by Donisi et al $11 \%$ patients were of age group $>65$ years while the remaining was of 15 64 years age group..$^{20}$ The mean age in our study was $32.4( \pm 12.6)$ years. It is similar to the findings in study by Appleby et al. ${ }^{21}$ who found the mean age of patients to be $35.4( \pm 11.7)$ years but much less than that in the study by Baeza et al who found the mean age to be 43.8 years. ${ }^{16}$ In our study $31.4 \%$ of patients were from Sunsari district alone, $31.1 \%$ from surrounding districts of Sunsari, 26.1\% from other Eastern Terai districts and only $11.3 \%$ from other Eastern Hill districts. However, according to the 2011 census, the population distribution in the eastern region was 13\% in Sunsari District, 36\% in surrounding districts of Sunsari, $25 \%$ in other Terai districts and $26 \%$ in other Eastern Hill districts. Also, of those from Sunsari district, 51\% were from Dharan Municipality only, the place where BPKIHS is located, while Dharan constituted only $16 \%$ of the total population of Sunsari as of 2011 census. ${ }^{15}$ This disproportionately high representation from Sunsari district and Dharan Municipality could be attributed to the location of the hospital in the Sunsari district and Dharan municipality itself, thereby allowing easier access. Several studies have shown that increase in distance decreases the likelihood of service utilization in mental health. ${ }^{22-27}$ Zulian et al reported the caseload decreased with increasing distance and found a $60 \%$ decrease in inpatient wards at a distance of $10 \mathrm{~km} \cdot{ }^{26}$ Majority of patients $(88.4 \%)$ were Hindu by religion followed by Kirat(5.4\%). The effect of seasonality in the hospital admission rate and LoS has been reported by many studies. ${ }^{28-32}$ In our study, there were more admissions during month of March(10.2\%) as compared to other 
months. The length of stay was maximum(21.8 days) in May and minimum(17.7 days) in March and there was significant association of LoS with month of admission. Our findings of maximum LoS during May is similar to the findings by G. Singh et al in India that had found that the bed occupancy rate and LoS were both high in the summer months(May-July). ${ }^{30}$ In our case, May falls in summer season in Nepal and our findings are matching with this study.

Regarding the diagnostic categories, mood disorders were the commonest $(48.5 \%)$ followed by schizophrenia and substance use disorders. Affective disorders have been reported as the commonest diagnostic category in other studies as well. ${ }^{16,20,33}$ Baeza et al reported mood disorders $(60.3 \%)$ to be the commonest disorder in their study followed by schizophrenia and related disorders $(28.8 \%)$ and neurotic, stressrelated and somatoform disorders(3.4\%).16 Similarly, Barros et al reported in their study from Brazil that in general hospital, mood disorders were the commonest(43.5\%) followed by psychotic disorders(29.3\%), alcohol and other substance related disorders $(10.1 \%)$ and others(7.4\%). ${ }^{33}$ In our study, the mean LoS was $19.4( \pm 13.2)$ days with majority $(70.1 \%)$ of LoS of 8 28days, followed by $>28$ days $(18.2 \%)$ and 1 7 days $(12.7 \%)$. Our findings is similar to the findings of Barros et. al from Brazil who found that the mean LoS in general and psychiatric hospitals were $20.5 \pm 34$.2days and $20.9 \pm 68.6$ days respectively. ${ }^{33}$ There was relatively less psychiatric co-morbidity $(6.1 \%)$ recorded in our study though psychiatric co-morbidity have been reported as high as $45 \% .{ }^{34}$ In our clinical practice also, we see co-morbid psychiatric illnesses more frequently. Similarly, medical comorbidity was reported less in our case as compared to other studies. ${ }^{35}$ The reason for this low finding could be because of lack of clear protocol to record the co-morbid illnesses in the database. In our study, $26 \%$ of admissions were readmission cases. Donisi et $\mathrm{al}^{36}$ reported a 90days readmission rate of $32.5 \%$ in their study from Italy while Hodgson et al ${ }^{37}$ reported $41 \%$ readmission rate at 5years. The findings of our study is much lower than both these studies. Both the studies have been done in developed country setting where health systems are stronger and loss to follow up might be less as compared to our resource poor setting.

One of the major limitations of our study is being a retrospective, cross-sectional study, we could not find the causal association among various factors. Similarly, as the data was extracted from database, some of the inherent shortcomings of the database like poor recording of the co-morbidities have been reflected in this study.

\section{CONCLUSION:}

There were a total of 3877 admissions during the study period. The admissions from Sunsari district and Dharan municipality were disproportionately high indicating that proximity and access to the facility greatly determine the utilization of mental health services. The overall outcome was good with only three mortality in ten years despite regularly managing delirium tremens cases in the ward itself and $92 \%$ patients being discharged in improved state. Mood disorders were the commonest diagnosis followed by schizophrenia and related disorders.

\section{CONFLICT OF INTEREST: None}

\section{ACKNOWLEDGEMENT}

We would like to acknowledge the support provided to us by the Medical Records Section of B. P. Koirala Institute of Health Sciences, Dharan by providing us with the data needed for the study and the institute authorities for giving us the permission to conduct this study.

\section{REFERENCES:}

1. WHO | Mental Disorders [Internet]. WHO. World Health Organization; 2017 [cited 2017 Jul 20]. Available from: http://www.who.int/mediacentre/factsheets/fs396/en/

2. WHO-aims report on mental health system in Nepal. Kathmandu: World Health Organization; 2006.

3. Luitel NP, Jordans MJD, Adhikari A, Upadhaya N, Hanlon C, Lund C, et al. Mental health care in Nepal: Current situation and challenges for development of a district mental health care plan. Confl Health. 2015;9(1):1-11.

4. Central Beureau of Statistics (CBS). Nepal Census 2011 Preliminary Report [Internet]. Kathmandu; 2011. Available from: www.cbs.gov.np

5. Stevens A, Hammer K, Buchkremer G. A statistical model for length of psychiatric in-patient treatment and an analysis of contributing factors. Acta Psychiatr 
Scand [Internet]. 2001 Mar;103(3):203-11. Available from: http://www.ncbi.nlm.nih.gov/pubmed/11240577

6. Large MM, Paton $M B$, Sara $G$, Wright $M$, Nielssen $O B$. Measuring the distribution of the length of stay in acute psychiatric units. I Psychiatr Intensive Care [Internet]. 2012 Aug 5 [cited 2018 Mar 1];8(2):78-87. Available from: http://login.research4life.org/tacsgr1www_cambridge_ org/core/services/aop-cambridgecore/content/view/D8B3D8D2B834496645E4DAB4E E83DF31/S1742646411000227a.pdf/measuring_the_di stribution_of_the_length_of_stay_in_acute_psychiatric _units.pdf

7. Newman L, Harris $V$, Evans LJ, Beck A. Factors Associated with Length of Stay in Psychiatric Inpatient Services in London, UK. Psychiatr Q [Internet]. 2018 Mar 3 [cited 2018 Mar 1];89(1):33-43. Available from: https://link.springer.com/content/pdf/10.1007\%2Fs111 26-017-9498-7.pdf

8. McCrone P, Phelan M. Diagnosis and length of psychiatric in-patient stay. Psychol Med [Internet]. 1994 Nov 9 [cited 2017 Jul 20];24(4):1025. Available from:

https://www.cambridge.org/core/journals/psychological -medicine/article/diagnosis-and-length-of-psychiatricinpatientstay/B17407B0D1E72EA68F3E3C4AC9E55E2D\#

9. Chung $W$, Oh SM, Suh T, Lee YM, Oh BH, Yoon CW. Determinants of length of stay for psychiatric inpatients: Analysis of a national database covering the entire Korean elderly population. Health Policy (New York). 2010;94(2):120-8.

10. Douzenis A, Seretis D, Nika S, Nikolaidou P, Papadopoulou A, Rizos EN, et al. Factors affecting hospital stay in psychiatric patients: the role of active comorbidity. BMC Health Serv Res [Internet]. 2012 Dec 19 [cited 2017 Jul 19];12(1):166. Available from: https://link.springer.com/content/pdf/10.1186\%2F1472 -6963-12-166.pdf

11. Tulloch AD, Fearon P, David AS. Length of Stay of General Psychiatric Inpatients in the United States: Systematic Review. Adm Policy Ment Heal Ment Heal Serv Res [Internet]. 2011 May 7 [cited 2017 Jul 19];38(3):155-68. Available from: https://link.springer.com/content/pdf/10.1007\%2Fs104 88-010-0310-3.pdf

12. U.S. Department of health and human services. Health, United States, 2009. With Special Feature on Medical Technology [Internet]. 2010 [cited 2017 Jul 20]. Available https://www.cdc.gov/nchs/data/hus/hus09.pdf

13. Goldstein JM, Bassuk E., Holland SK, Zimmer D. Identifying catastrophic psychiatric cases: Targeting managed-care strategies. Med Care. 1988;26(8):790-9.

14. Tulloch AD, David AS, Thornicroft G. Exploring the predictors of early readmission to psychiatric hospital. Epidemiol Psychiatr Sci [Internet]. 2016 Apr 23 [cited 2017 Jul 22];25(2):181-93. Available from: https://www.cambridge.org/core/services/aop- cambridge-

core/content/view/26F3450AE6611EB5C7F8B82F372 1B457/S2045796015000128a.pdf/exploring_the_predic tors_of_early_readmission_to_psychiatric_hospital.pdf

15. Central Bureau of Statistics, National Planning Commission G of N. National Population and Housing Census 2011(National Report) [Internet]. Vol. 1, National Population and Housing Census 2011 (National Report). Kathmandu, Nepal; 2012 [cited 2018 Mar 12]. Available from: http://cbs.gov.np/image/data/Population/National Report/National Report.pdf

16. Baeza FL, da Rocha NS, Fleck MP. Predictors of length of stay in an acute psychiatric inpatient facility in a general hospital: a prospective study. Rev Bras Psiquiatr [Internet]. 2017 Jul 6 [cited 2018 Mar 1];40(1):89-96. Available from: http://login.research4life.org/tacsgrOwww_scielo_br/pd f/rbp/2017nahead/1516-4446-rbp1516444620162155.pdf

17. Lerner Y, Zilber N. Predictors of cumulative length of psychiatric inpatient stay over one year: A national case register study. Isr J Psychiatry Relat Sci [Internet]. 2010 [cited 2017 Jul 19];47(4):304-7. Available from: https://doctorsonly.co.il/wpcontent/uploads/2011/12/2010_4_10.pdf

18. Pokharel S. Gender Discrimination: Women Perspective. Nepal J Dev Rural Stud [Internet]. 2008;2(5):80-7. Available from: https://www.researchgate.net/publication/215457309_ Gender_Discrimination_Women_Perspective

19. Asian Development Bank, ADB. Overview of Gender Equality and Social Inclusion (GESI) in Nepal [Internet]. Mandaluyong, Phillipines: Asian Development Bank; 2010 [cited 2018 Mar 12]. 50 p. Available from: https://www.adb.org/sites/default/files/institutionaldocument/32237/cga-nep-2010.pdf

20. Donisi V, Tedeschi F, Salazzari D, Amaddeo F. Preand post-discharge factors influencing early readmission to acute psychiatric wards: Implications for quality-of-care indicators in psychiatry. Gen Hosp Psychiatry [Internet]. 2016;39:53-8. Available from: http://dx.doi.org/10.1016/j.genhosppsych.2015.10.009

21. Appleby L, Desai PN, Luchins DJ, Gibbons RD, Hedeker DR. Length of stay and recidivism in schizophrenia: a study of public psychiatric hospital patients. Am J Psychiatry [Internet]. 1993 Jan [cited 2017 Jul 19];150(1):72-6. Available from: http://login.research4life.org/tacsgr0ajp_psychiatryonli ne_org/doi/pdf/10.1176/ajp.150.1.72

22. Bürgy $R$, Häfner-Ranabauer $W$. Utilization of the psychiatric emergency service in Mannheim: Ecological and distance-related aspects. Soc Psychiatry Psychiatr Epidemiol [Internet]. 1998 Oct 1 [cited 2018 Mar 12];33(11):558-67. Available from: https://link.springer.com/content/pdf/10.1007\%2Fs001 270050094.pdf 
J Psychiatrists' Association of Nepal Vol .6, No.2, 2017

23. McCarthy JF, Valenstein M, Zivin K, Zeber JE, Kilbourne AM. Access-Related Measures and Out-ofSystem Utilization Among Veterans With Bipolar Disorder. Psychiatr Serv [Internet]. 2010 Oct [cited 2018 Mar 12];61(10):1035-8. Available from: http://login.research4life.org/tacsgr1ps_psychiatryonlin e_org/doi/pdfplus/10.1176/ps.2010.61.10.1035

24. Sohler KB, Thompson JD. Jarvis' law and the planning of mental health services. Influence of accessibility, poverty, and urbanization on first admissions to Connecticut State hospitals. Public Heal reports (Washington, DC 1896) [Internet]. 1970 Jun [cited 2018 Mar 12];85(6):503-10. Available from: http://login.research4life.org/tacsgr1www_ncbi_nlm_n ih_gov/pmc/articles/PMC2031739/pdf/pubhealthrepori g01054-0037.pdf

25. Packness $A$, Waldorff FB, Christensen $R$ dePont, Hastrup LH, Simonsen E, Vestergaard $M$, et al. Impact of socioeconomic position and distance on mental health care utilization: a nationwide Danish follow-up study. Soc Psychiatry Psychiatr Epidemiol [Internet]. 2017 Nov 28;52(11):1405-13. Available from: http://link.springer.com/10.1007/s00127-017-1437-2

26. Zulian G, Donisi V, Secco G, Pertile R, Tansella M, Amaddeo F. How are caseload and service utilisation of psychiatric services influenced by distance? A geographical approach to the study of community-based mental health services. Soc Psychiatry Psychiatr Epidemiol [Internet]. 2011 [cited 2018 Mar 12];46(9):881-91. Available from: https://link.springer.com/content/pdf/10.1007\%2Fs001 27-010-0257-4.pdf

27. Stulz N, Pichler EM, Kawohl W, Hepp U. The gravitational force of mental health services: Distance decay effects in a rural Swiss service area. BMC Health Serv Res [Internet]. 2018 [cited 2018 Mar 12];18(1). Available from: https://bmchealthservres.biomedcentral.com/track/pdf/1 0.1186/s12913-018-2888-

1 ? site $=$ bmchealthservres. biomedcentral.com

28. Federman EJ, Drebing CE, Boisvert $C$, Penk $W$, Binus $G$, Rosenheck R. Relationship Between Climate and Psychiatric Inpatient Length of Stay in Veterans Health Administration Hospitals. Am J Psychiatry [Internet]. 2000 Oct [cited 2018 Mar 13];157(10):1669-73. Available from: https://ajp.psychiatryonline.org/doi/pdf/10.1176/appi.aj p.157.10.1669

29. Fisekovic S, Licanin I, Cesir A. Prevalence of Neurotic, Somatoform and Stress Induced Disorders in Relation to the Seasons and Climatic Factors During the 2010/2011. Mater Socio Medica [Internet]. 2012 [cited 2018 Mar 13];24(3):190. Available from: https://www.ncbi.nlm.nih.gov/pmc/articles/PMC37323 51/pdf/MSM-24-190.pdf

30. Singh G, Chavan B, Arun P, Sidana A. Seasonal pattern of psychiatry service utilization in a tertiary care hospital. Indian J Psychiatry [Internet]. 2007 Apr [cited 2018 Mar 13];49(2):91. Available from: http://www.ncbi.nlm.nih.gov/pubmed/20711389

31. Trang PM, Rocklöv J, Giang KB, Nilsson $M$. Seasonality of hospital admissions for mental disorders in Hanoi, Vietnam. Glob Health Action [Internet]. 2016 Dec 25 [cited 2018 Mar 13];9(1):32116. Available from:

https://www.ncbi.nlm.nih.gov/pmc/articles/PMC50020 36/pdf/GHA-9-32116.pdf

32. Licanin I, Fisekovic S, Babic S. Admission Rate of Patients with Most Common Psychiatric Disorders in Relation to Seasons and Climatic Factors During 2010/2011. Mater Socio Medica [Internet]. 2012 [cited 2018 Mar 13];24(2):94. Available from: https://www.ncbi.nlm.nih.gov/pmc/articles/PMC37323 28/pdf/MSM-24-94.pdf

33. Barros REM, de Azevedo Marques JM, Santos JLF, Zuardi AW, Del-Ben CM. Impact of length of stay for first psychiatric admissions on the ratio of readmissions in subsequent years in a large Brazilian catchment area. Soc Psychiatry Psychiatr Epidemiol [Internet]. 2016 Apr 22;51(4):575-87. Available from: http://link.springer.com/10.1007/s00127-016-1175-x

34. van Loo HM, Romeijn J-W, de Jonge $P$, Schoevers RA. Psychiatric comorbidity and causal disease models. Prev Med (Baltim) [Internet]. 2013 Dec [cited 2018 Mar 15];57(6):748-52. Available from: https://ac.elscdn.com/S0091743512005439/1-s2.0

S0091743512005439-main.pdf?_tid=c560370c-53ef$4 f 70-b f 1 f-$

cf4ee0c5d57eEacdnat=1521082705_2c14e97da3bf2ee9 04deefe39102c985

35. Scott KM, Lim C, Al-Hamzawi A, Alonso J, Bruffaerts $R$, Caldas-de-Almeida JM, et al. Association of Mental Disorders With Subsequent Chronic Physical Conditions. JAMA Psychiatry [Internet]. 2016 Feb 1 [cited 2018 Mar 15];73(2):150. Available from: https://www.ncbi.nlm.nih.gov/pmc/articles/PMC53339 21/pdf/nihms848687.pdf

36. Donisi V, Tedeschi F, Salazzari D, Amaddeo F. Preand post-discharge factors influencing early readmission to acute psychiatric wards: implications for quality-of-care indicators in psychiatry. Gen Hosp Psychiatry [Internet]. 2016 Mar [cited 2017 Jul 22];39:53-8. Available from: http://ac.elscdn.com/S0163834315002352/1-s2.0S0163834315002352-main.pdf?_tid=90e14686-6eaf$11 e 7-a 1 d d-$ 00000aacb35dEacdnat $=1500708778 \_9 f 5 b a a 05565408$ $1 e 6 a 9809 e 6 b f 05 b 9 b 6$

37. Hodgson RE, Lewis M, Boardman AP. Prediction of readmission to acute psychiatric units. Soc Psychiatry Psychiatr Epidemiol [Internet]. 2001 Aug 1 [cited 2018 Mar 15];36(6):304-9. Available from: http://link.springer.com/10.1007/s001270170049 